\title{
Energy and macronutrient intakes in Belgium: results from the first National Food Consumption Survey
}

\author{
E. Temme ${ }^{1}$, I. Huybrechts ${ }^{2}$, S. Vandevijvere ${ }^{*}$, S. De Henauw ${ }^{2}$, A. Leveque ${ }^{3}$, Marcel Kornitzer $^{3}$, \\ G. De Backer ${ }^{2}$ and H. Van Oyen ${ }^{1}$ \\ ${ }^{1}$ Unit of Epidemiology, Scientific Institute of Public Health, J. Wytsmanstraat 14, B-1050 Brussels, Belgium \\ ${ }^{2}$ Department of Public Health, Ghent University, Ghent, Belgium \\ ${ }^{3}$ Department of Epidemiology and Health Promotion, School of Public Health, Université Libre Bruxelles, Brussels, Belgium
}

(Received 18 August 2009 - Revised 12 January 2010 - Accepted 14 January 2010 - First published online 26 February 2010)

Belgium until recently lacked a systematic survey of dietary habits of its inhabitants. The present study evaluated dietary composition in Belgium with respect to energy and macronutrient intakes. Information on food intake was collected using a repeated non-consecutive $24 \mathrm{~h}$ recall (2-8 weeks apart) with the validated software package EPIC-SOFT, in combination with a FFQ (self-administered) covering sixty food items. The database of consumed food items was linked to food composition data. Usual macronutrient intake was estimated by the Nusser method. A representative sample of the Belgian population was randomly selected from the national register following a multi-stage procedure. Information on dietary intake was obtained from 3245 subjects aged 15 years and older. Mean energy percentage (E \%) of total fat (37.9E \%) and SFA $(16.0 \mathrm{E} \%)$ was higher than the dietary reference intakes (DRI). Mean E \% of total carbohydrates $(45.8 \mathrm{E} \%)$ was lower than the DRI, while mean E $\%$ of mono/disaccharides was 20.3. Total fat and SFA intakes were higher and total carbohydrate and sugar intakes were lower in the older age categories than in the younger age categories. The percentage of energy from SFA intake was lower and that from carbohydrates was higher than that found in an earlier Belgian study. Further efforts are necessary to improve dietary macronutrient intake, taking into account differences in age categories. In addition, it will be important to monitor its changes regularly using trend analyses.

Food consumption surveys: Macronutrients: Fat: Carbohydrate: Protein

Belgium is one of the few countries in Europe that until recently lacked a systematic survey of dietary habits of its inhabitants. The last study including a dietary assessment at the population level was the Belgian Interuniversity Research on Nutrition and Health $(\mathrm{BIRNH})^{(1)}$, which was held from 1980 to 1985 . The present study included an age- and sex-stratified random sample of the population, aged 25-74 years, from the voting list. One-day dietary records were used for assessing diet. Afterwards, some local surveys had been carried out, but these were not representative of the Belgian population. The BIRNH study had already indicated that macronutrient intake in the adult population deviated from the dietary reference intakes ${ }^{(2)}$ set by the Superior Health Council ${ }^{(3)}$. Especially, overall fat intake and intake of SFA were higher than that recommended $(37.0 v$ v. 30 energy percentage $(\mathrm{E} \%)$ and $15.6 v$. a maximum of $10 \mathrm{E} \%$, respectively) ${ }^{(2)}$. In the period 1985-2004, no further monitoring of the Belgian food consumption pattern was done. However, as dietary habits are changing continuously over time, it is important to be aware of any gaps within the current dietary patterns in order to develop effective policies on nutrition.
Therefore, in 2004, at the request of the Ministry of Social Affairs, Public Health and Environment, the Belgian National Food Consumption Survey (BNFCS) was initiated. The main objective of the BNFCS was to monitor the adequacy of food and nutrient intakes in the population. The objective of the present paper was to evaluate current dietary energy and macronutrient intakes, and compare them with the national dietary guidelines. In addition, the main food sources of the selected macronutrients were described.

\begin{abstract}
Methods
The study design of this survey followed the recommendations of the European Food Consumption Survey Method project $^{(4-6)}$ to a large extent. This project envisaged the formulation of recommendations to harmonise the methodology for the collection of food composition data among adults ( $>15$ years) across Europe. The present study was conducted according to the guidelines laid down in the Declaration of Helsinki, and all procedures involving human subjects were approved by the medical ethical committee of
\end{abstract}

Abbreviations: BIRNH, Belgian Interuniversity Research on Nutrition and Health; BNFCS, Belgian National Food Consumption Survey; E \%, energy percentage; EI, energy intake.

* Corresponding author: Stefanie Vandevijvere, fax +32 2642 5410, email stefanie.vandevijvere@iph.fgov.be 
the Scientific Institute of Public Health. Written or verbal informed consent was obtained from all subjects. An indepth description of the study design and methodology used is given elsewhere ${ }^{(7)}$.

\section{Sample selection}

For the BNFCS, a representative sample of the Belgian population was randomly selected from the national register. The target population was defined as all the people aged 15 years and older residing in private households in Belgium. The sampling method followed a multi-stage procedure. The sample was stratified into four age groups (15-18, 19-59, 60-74 and older than 75 years of age) and by sex. No upper age limit was set within this survey. Belgium was divided into three regions and eleven provincial clusters. The participants of the present study were sampled in a way that the population densities of the region, of the provinces and of the municipalities were taken into account. Each selected municipality included at least fifty individuals. However, larger cities could have a multiple of fifty individuals.

For each selected individual, three individuals were nominated beforehand who could serve as replacements in case the selected individuals did not participate in the survey. The selected individuals and their stand-ins lived in the same statistical sector of the same commune and in a household of the same size and had the same age and sex. Of the 7543 contactable individuals, $42 \%$ participated in the study. Participation rate was $40.6 \%$ for men and $43.4 \%$ for women. Main reasons for not participating were lack of interest $(54 \%)$, lack of time (17\%) and health problems (12\%).

\section{Study design}

Participants were invited to participate in the study by a letter and leaflet. A trained dietitian visited the participants twice.

During the first visit, the participants completed a face-to-face questionnaire on general health, lifestyle and physical activity. This questionnaire also included self-reported weight and height.

A $24 \mathrm{~h}$ recall assessed dietary intake of the previous day. During the second visit, 2-8 weeks later (median of 3 weeks), a second $24 \mathrm{~h}$ diet recall was performed. In the time between these two visits, participants were asked to complete a FFQ. The dietitian checked the questionnaires for completeness. All dietitians followed a compulsory two and half-day training session. During this session, the dietitians were trained in methods to approach the selected persons, to assess diets by $24 \mathrm{~h}$ recalls and to use the computer software EPIC-SOFT in a standardised way.

\section{Dietary assessment}

Information on food intake was collected using a repeated nonconsecutive $24 \mathrm{~h}$ recall (face to face) in combination with a FFQ (self-administered) covering sixty food items. The 1-year survey was distributed equally over the seasons and days of the week. During a $24 \mathrm{~h}$ recall, the participants reported the types and quantities of all foods and beverages that were consumed during the preceding day. To obtain a standardised $24 \mathrm{~h}$ recall interview, the validated software package EPICSOFT was used ${ }^{(8)}$. EPIC-SOFT is designed for uniform data collection in the ten countries participating in the European Prospective Investigation into Cancer study. The software allows obtaining a very detailed description and quantification of foods, recipes and supplements consumed. Quantification of the consumed foods is supported by a picture book that comprises photographs of foods in different portion sizes.

\section{Statistical analysis}

To calculate dietary intake of energy and macronutrients, the database of consumed food items was linked to food composition data based on the following database: the Belgian food composition database ${ }^{(9)}$, the Dutch food composition database $^{(10)}$, the food composition database of the Belgian Institute Paul Lambin ${ }^{(11)}$ and the McCance and Widdowson's food composition database ${ }^{(12)}$. Energy intake (EI) was calculated by including and excluding energy from alcohol. Macronutrient intake in percentage of energy was calculated from energy excluding alcohol.

The BMR was estimated using the Schofield equations ${ }^{(13)}$ based on weight, height, age and sex. As a measure for the degree of underreporting, the ratio of reported daily EI divided by the estimated BMR was calculated.

This ratio was compared with the Goldberg et al. ${ }^{(14)}$ cut-off for plausible EI, depending on the sample size and the number of reporting days. The level of physical activity was set for all respondents at 1.55 . At the individual level, respondents with two $24 \mathrm{~h}$ recalls and EI/BMR lower than 0.965 were defined as underreporters.

Because of day-to-day variations in individual nutrient intakes, intake data for a large number of days are typically needed to determine usual nutrient and/or EI for an individual $^{(15-19)}$. It is seldom feasible to collect these required long-term data for each person. Therefore, a statistical modelling method that accounts for within-individual variation in nutrient intakes while requiring relatively few days of intake per individual is needed (the Nusser method) ${ }^{(20)}$. This method is recommended by the Institute of Medicine ${ }^{(21)}$. With this method, the intra-individual variance is estimated and subtracted from the total variance. In addition, data are transformed to a normal distribution. The statistical method used for estimating the usual intake distributions and the proportion below or above the defined cut-off values was developed at Iowa State University ${ }^{(22)}$. The software program used to carry out the method was Software for Intake Distribution Estimation ${ }^{(23)}$. The reported usual dietary intakes were weighed and adjusted for the age and sex distribution of the Belgian population and adjusted for interview day and season. The complex sampling design was taken into account in the analyses. Analyses of contributions of food groups to nutrient intakes were performed with SPSS 14.0 (SPSS, Inc., Chicago, IL, USA).

Under- or misreporters have not been excluded from the analyses of macronutrient intakes because exclusion of presumed misreporters could bias the results as well.

\section{Results \\ Energy intake}

The mean EI was 6908 (SE 44) kJ/d for women and 10343 (SE 73) kJ/d for men. Mean EI decreased with age for both 
Table 1. Average* daily intake of energy and fats of 3245 participants in the Belgian Food Consumption Survey (Mean values with their standard errors)

\begin{tabular}{|c|c|c|c|c|c|c|c|c|c|c|c|c|c|}
\hline \multirow[b]{2}{*}{ Sex and age class } & \multirow[b]{2}{*}{$n$} & \multicolumn{2}{|c|}{$\begin{array}{l}\text { Energy intake } \\
(\mathrm{kJ} / \mathrm{d})\end{array}$} & \multicolumn{2}{|c|}{$\begin{array}{l}\text { Energy intake } \\
\text { excluding } \\
\text { alcohol }(\mathrm{kJ} / \mathrm{d})\end{array}$} & \multicolumn{2}{|c|}{ Total fat (E \%) } & \multicolumn{2}{|c|}{ SFA (E \%) } & \multicolumn{2}{|c|}{ MUFA (E \%) } & \multicolumn{2}{|c|}{ PUFA (E \%) } \\
\hline & & Mean & SE & Mean & $\mathrm{SE}$ & Mean & $\mathrm{SE}$ & Mean & $\mathrm{SE}$ & Mean & SE & Mean & SE \\
\hline Total population & 3245 & 8560 & 51 & 8125 & 47 & 37.9 & 0.1 & $15 \cdot 6$ & 0.06 & 13.8 & 0.04 & 6.9 & 0.04 \\
\hline$<18$ & 806 & 9418 & 97 & 9251 & 93 & $36 \cdot 2$ & 1.3 & 14.4 & 0.5 & 13.0 & 0.06 & $6 \cdot 7$ & 0.06 \\
\hline $19-59$ & 873 & 8908 & 104 & 8439 & 98 & 37.6 & 0.2 & 15.4 & 0.1 & 13.7 & 0.07 & $7 \cdot 0$ & 0.08 \\
\hline $60-74$ & 822 & 7807 & 78 & 7297 & 70 & 39.0 & 0.2 & $16 \cdot 2$ & 0.1 & $14 \cdot 1$ & 0.09 & $6 \cdot 8$ & 0.09 \\
\hline$>75$ & 744 & 6979 & 75 & 6699 & 73 & 39.8 & 0.3 & $17 \cdot 3$ & 0.2 & 14.0 & 0.1 & $6 \cdot 3$ & 0.09 \\
\hline Women & 1622 & 6908 & 44 & 6669 & 44 & $37 \cdot 0$ & 0.2 & $15 \cdot 6$ & 0.09 & $13 \cdot 4$ & 0.06 & $6 \cdot 7$ & 0.06 \\
\hline$<18$ & 401 & 7715 & 78 & 7657 & 78 & 35.7 & 0.3 & 14.5 & 0.1 & 12.9 & 0.1 & $6 \cdot 7$ & 0.1 \\
\hline $19-59$ & 460 & 7029 & 87 & 6782 & 88 & $36 \cdot 4$ & 0.3 & $15 \cdot 2$ & 0.1 & 13.3 & 0.1 & $6 \cdot 9$ & 0.1 \\
\hline $60-74$ & 406 & 6682 & 80 & 6397 & 77 & $38 \cdot 1$ & 0.3 & $16 \cdot 1$ & 0.2 & 13.8 & 0.1 & 6.5 & 0.1 \\
\hline$>75$ & 355 & 6201 & 78 & 5991 & 77 & 39.6 & 0.4 & $17 \cdot 7$ & 0.3 & $14 \cdot 0$ & 0.2 & 5.9 & 0.1 \\
\hline Men & 1623 & 10343 & 73 & 9690 & 69 & 38.9 & 0.2 & $15 \cdot 7$ & 0.09 & $14 \cdot 1$ & 0.06 & $7 \cdot 1$ & 0.06 \\
\hline$<18$ & 405 & 11042 & 131 & 10770 & 128 & $36 \cdot 7$ & 0.2 & 14.4 & 0.1 & $13 \cdot 1$ & 0.06 & $6 \cdot 6$ & 0.07 \\
\hline $19-59$ & 413 & 10786 & 148 & 10100 & 139 & 38.7 & $2 \cdot 0$ & $15 \cdot 6$ & 0.1 & $14 \cdot 1$ & 0.1 & $7 \cdot 1$ & 0.1 \\
\hline $60-74$ & 416 & 9088 & 108 & 8322 & 99 & $40 \cdot 0$ & 0.3 & $16 \cdot 4$ & 0.2 & 14.5 & 0.1 & $7 \cdot 2$ & 0.1 \\
\hline$>75$ & 389 & 8339 & 112 & 7924 & 112 & $40 \cdot 2$ & 0.4 & $16 \cdot 7$ & 0.2 & $14 \cdot 0$ & 0.1 & $7 \cdot 0$ & 0.1 \\
\hline
\end{tabular}

$\mathrm{E} \%$, energy percentage; $n$, number of respondents.

* Weighed average corrected for interview day and season.

women and men (Table 1). The percentage of underreporters was higher in women $(26 \%)$ than in men $(14 \%)$. Excluding underreporters, the mean EI was about $840 \mathrm{~kJ} / \mathrm{d}$ higher and was $7761(\mathrm{SE} 25) \mathrm{kJ} / \mathrm{d}$ for women and 11079 (SE 56) kJ/d for men.

\section{Macronutrient intake and food sources}

The mean daily intake of macronutrients is presented in Tables 1 and 2 . The E $\%$ from fat was slightly lower and that from carbohydrates was higher in women (37.0 (SE 0.2 ) E \% fat and 46.4 (SE 0.2) E \% carbohydrates) than in men (38.9 (SE 0.2) E \% fat and 45.0 (SE 0.2) carbohydrates).
The distribution over the different fatty acid groups was similar for women and men. For the total population, intake of SFA, MUFA and PUFA was 15.6 (SE 0.06), 13.8 (SE 0.04), 6.9 (SE 0.04) E \%, respectively. Total fat intake increased and carbohydrates intake decreased in the older age categories. For fat, this was mainly due to a higher SFA intake and it was not related to PUFA. For carbohydrates, a lower intake of mono- and disaccharides was observed in the higher age categories than in the younger age categories.

The food groups that contributed most to total fat, SFA and PUFA intakes are presented in Table 3. The fat food group (spread and baking fat), meat products and dairy products explained almost two-thirds of total and saturated fat intake.

Table 2. Average* daily intake of carbohydrates and proteins of 3245 participants in the Belgian Food Consumption Survey (Mean values with their standard errors)

\begin{tabular}{|c|c|c|c|c|c|c|c|c|c|}
\hline \multirow[b]{2}{*}{ Sex and age class } & \multirow[b]{2}{*}{$n$} & \multicolumn{2}{|c|}{$\begin{array}{l}\text { Carbohydrates } \\
(E \%)\end{array}$} & \multicolumn{2}{|c|}{$\begin{array}{c}\text { Mono/ } \\
\text { disaccharides } \\
(\mathrm{E} \%)\end{array}$} & \multicolumn{2}{|c|}{$\begin{array}{c}\text { Polysaccharides } \\
\text { (E \%) }\end{array}$} & \multicolumn{2}{|c|}{ Proteins (E \%) } \\
\hline & & Mean & $\mathrm{SE}$ & Mean & SE & Mean & SE & Mean & SE \\
\hline Total population & 3245 & $45 \cdot 8$ & 0.1 & $20 \cdot 3$ & 0.1 & 24.4 & 0.09 & $16 \cdot 3$ & 0.06 \\
\hline$<18$ & 806 & $50 \cdot 1$ & 0.2 & $24 \cdot 2$ & 0.2 & $25 \cdot 0$ & 0.2 & $13 \cdot 7$ & 0.07 \\
\hline $19-59$ & 873 & $46 \cdot 1$ & 0.2 & 20.5 & 0.2 & $24 \cdot 6$ & 0.2 & $16 \cdot 4$ & 0.1 \\
\hline $60-74$ & 822 & $44 \cdot 2$ & $0 . \overline{2}$ & $19 \cdot 2$ & 0.2 & $24 \cdot 0$ & 0.2 & $16 \cdot 8$ & 0.1 \\
\hline$>75$ & 744 & 43.5 & 0.2 & $18 \cdot 7$ & 0.2 & $23 \cdot 6$ & 0.2 & $16 \cdot 6$ & 0.1 \\
\hline Women & 1622 & $46 \cdot 4$ & 0.2 & $21 \cdot 2$ & 0.2 & $24 \cdot 4$ & 0.1 & $16 \cdot 6$ & 0.08 \\
\hline$<18$ & 401 & $50 \cdot 6$ & 0.3 & $24 \cdot 2$ & 0.3 & 25.5 & 0.2 & $13 \cdot 7$ & 0.1 \\
\hline $19-59$ & 460 & $46 \cdot 9$ & 0.3 & $21 \cdot 4$ & 0.3 & $24 \cdot 8$ & 0.2 & $16 \cdot 7$ & 0.2 \\
\hline $60-74$ & 406 & $45 \cdot 2$ & 0.3 & $20 \cdot 6$ & 0.3 & 23.7 & 0.2 & $16 \cdot 7$ & 0.1 \\
\hline$>75$ & 355 & $43 \cdot 3$ & 0.3 & $19 \cdot 2$ & 0.3 & $23 \cdot 0$ & 0.2 & $17 \cdot 0$ & 0.2 \\
\hline Men & 1623 & $45 \cdot 0$ & 0.2 & $19 \cdot 3$ & 0.2 & $24 \cdot 4$ & 0.1 & $16 \cdot 0$ & 0.08 \\
\hline$<18$ & 405 & 49.5 & 0.2 & $24 \cdot 2$ & 0.3 & 24.5 & 0.2 & $13 \cdot 8$ & 0.1 \\
\hline $19-59$ & 413 & $45 \cdot 2$ & 0.3 & $19 \cdot 4$ & 0.3 & $24 \cdot 3$ & 0.2 & $16 \cdot 0$ & 0.2 \\
\hline $60-74$ & 416 & $43 \cdot 1$ & 0.3 & $17 \cdot 8$ & 0.2 & $24 \cdot 3$ & 0.3 & $16 \cdot 9$ & 0.1 \\
\hline$>75$ & 389 & $43 \cdot 7$ & 0.4 & $17 \cdot 7$ & 0.3 & $24 \cdot 7$ & 0.3 & $16 \cdot 0$ & $0 \cdot 2$ \\
\hline
\end{tabular}

$\mathrm{E} \%$, energy percentage; $n$, number of respondents.

* Weighed average corrected for interview day and season. 
Table 3. Food groups with the highest average proportional contribution to fat and SFA and PUFA intakes ( $>2 \%$ )

\begin{tabular}{|c|c|c|c|c|c|}
\hline \multicolumn{2}{|l|}{ Fats } & \multicolumn{2}{|l|}{ SFA } & \multicolumn{2}{|l|}{ PUFA } \\
\hline Food group & $\begin{array}{c}\text { Contribution } \\
(\%)\end{array}$ & Food group & $\begin{array}{c}\text { Contribution } \\
(\%)\end{array}$ & Food group & $\begin{array}{c}\text { Contribution } \\
(\%)\end{array}$ \\
\hline Fat & $27 \cdot 1$ & Fat & $25 \cdot 0$ & Fat & 32.4 \\
\hline Margarines & 11.8 & Butter & $13 \cdot 0$ & Margarines & $22 \cdot 8$ \\
\hline Butter & 8.9 & Margarines & $8 \cdot 3$ & Vegetable oils & 3.8 \\
\hline Vegetable oils & 3.3 & Dairy products & $22 \cdot 3$ & Deep frying fats & 3.3 \\
\hline Deep frying fats & $2 \cdot 6$ & Cheeses (including fresh) & 14.4 & Butter & $2 \cdot 0$ \\
\hline Meat (products) & $18 \cdot 1$ & Milk & 3.0 & Condiments/sauces & 21.9 \\
\hline Processed meat & 6.9 & Meat (products) & $16 \cdot 4$ & Mayonnaises & $20 \cdot 2$ \\
\hline Fresh meat & 4.9 & Processed meat & 5.7 & Meat (products) & $12 \cdot 9$ \\
\hline Pork & $2 \cdot 1$ & Fresh meat & 4.8 & Processed meat & $5 \cdot 4$ \\
\hline Dairy products & $14 \cdot 0$ & Pork & $2 \cdot 0$ & Fresh meat & $3 \cdot 0$ \\
\hline Cheeses (including fresh) & $9 \cdot 0$ & Cakes & 12.5 & Cereal (products) & $12 \cdot 2$ \\
\hline Milk & $2 \cdot 0$ & Cakes, pies, pastries, puddings & $7 \cdot 3$ & Bread & 8.7 \\
\hline Cakes & 9.6 & Dry cakes, biscuits & $5 \cdot 2$ & Salty biscuits & $2 \cdot 0$ \\
\hline Cakes, pies, pastries, puddings & $5 \cdot 7$ & Sugar/confectionery & $7 \cdot 2$ & Cakes & 5.6 \\
\hline Dry cakes, biscuits & 3.9 & Chocolate (products) & 5.5 & Cakes, pies, pastries, puddings & $3 \cdot 3$ \\
\hline Condiments/sauces & 9.4 & Cereal (products) & $6 \cdot 4$ & Dry cakes, biscuits & $2 \cdot 3$ \\
\hline Mayonnaises & $7 \cdot 3$ & Bread & $4 \cdot 2$ & Sugar/confectionery & 3.9 \\
\hline Cereal (products) & 8.0 & Condiments/sauces & 3.9 & Chocolate (products) & 3.6 \\
\hline Bread & $5 \cdot 1$ & Mayonnaises & $2 \cdot 2$ & Fruit & $2 \cdot 9$ \\
\hline Sugar/confectionery & $6 \cdot 1$ & & & Nuts and seeds & $2 \cdot 8$ \\
\hline Chocolate (products) & 4.9 & & & Dairy products & $2 \cdot 3$ \\
\hline
\end{tabular}

Within the fat food group, butter $(13 \%)$ and margarines $(8 \%)$ were the most important contributors of SFA intake. Cheeses $(14 \%)$ were the most important contributors of SFA intake in the dairy product food group. For PUFA intake, margarines $(23 \%)$ and mayonnaises $(20 \%)$ were the most important sources. Fish contributed $1.6 \%$ to PUFA intake.

Intake of polysaccharides was 24.4 (SE 0.09) E \%, and it did not differ between women and men. Intake of mono- and disaccharides was slightly higher in women (21.2 (SE 0.2) E \%) than in men (19.3 (SE 0.2) E \%). The main contributors of intake of polysaccharides were bread $(50 \%)$, potatoes $(12 \%)$ and pasta, rice and other grains (10\%; Table 4).
For the intake of mono- and disaccharides, carbonated/soft/ isotonic drinks $(19 \%)$ were the most important sources followed by sugar/honey/jam $(10 \%)$, pit fruits $(6 \%)$ and fruit and vegetable juices $(6 \%)$.

\section{Discussion}

Reported energy intake is low

For $20 \%$ of the respondents, the reported EI was lower than the cut-offs that Goldberg et al. ${ }^{(24)}$ used to estimate energy requirements taking into account the reported weight and

Table 4. Food groups with the highest average proportional contribution to polysaccharides and mono/disaccharides ( $\geq 2 \%)$

\begin{tabular}{|c|c|c|c|}
\hline \multicolumn{2}{|c|}{ Polysaccharides } & \multicolumn{2}{|l|}{ Mono/disaccharides } \\
\hline Food group & Contribution (\%) & Food group & Contribution (\%) \\
\hline Cereal (products) & $67 \cdot 3$ & Non-alcoholic drinks & $25 \cdot 0$ \\
\hline Bread & $50 \cdot 3$ & Carbonated/soft/isotonic drinks & $18 \cdot 5$ \\
\hline Pasta, rice, other grains & 9.5 & Fruit and vegetable juice & $6 \cdot 2$ \\
\hline Breakfast cereals & $2 \cdot 7$ & Sugar/confectionery & $18 \cdot 9$ \\
\hline Potatoes/other tubers & $15 \cdot 9$ & Sugar, honey, jam & $9 \cdot 6$ \\
\hline Potatoes & 11.8 & Chocolate (products) & $6 \cdot 3$ \\
\hline Fried potato products & 3.9 & Fruit & 14.7 \\
\hline Cakes & 9.2 & Pit fruits & $6 \cdot 4$ \\
\hline Cakes, pies, pastries, puddings & $4 \cdot 8$ & Fruits unclassified & $3 \cdot 6$ \\
\hline \multirow{12}{*}{ Dry cakes, biscuits } & 4.4 & Dairy products & $13 \cdot 6$ \\
\hline & & Milk & 4.4 \\
\hline & & Yogurt & 3.9 \\
\hline & & Cream desserts, puddings (milk-based) & $2 \cdot 7$ \\
\hline & & Cakes & 11.5 \\
\hline & & Cakes, pies, pastries, puddings & 5.9 \\
\hline & & Dry cakes, biscuits & $5 \cdot 6$ \\
\hline & & Alcoholic drinks & $5 \cdot 0$ \\
\hline & & Beer, cider & 3.6 \\
\hline & & Cereal (products) & $4 \cdot 1$ \\
\hline & & Bread & $2 \cdot 2$ \\
\hline & & Vegetables & $3 \cdot 3$ \\
\hline
\end{tabular}


physical activity level. Since the weight of the respondents (for the Schofield equation) has been self-reported, these results should be interpreted with caution, given the fact that some individuals (e.g. obese persons) are known to underreport their own weight ${ }^{(25-28)}$. In the ten countries participating in the European Prospective Investigation into Cancer survey, the percentage of subjects identified as extreme under reporters was $13.8 \%$ for women and $10.3 \%$ for men ${ }^{(29)}$. In the present study, the percentage of women $(26 \%)$ underreporting their food intake was higher than the percentage of men $(14 \%)$. Underreporting of food intake is a wellrecognised phenomenon and common problem to dietary surveys worldwide ${ }^{(30,31)}$. Methods to improve the quality of dietary data, such as adding external markers of intake, must be explored further. Under- or misreporters have not been excluded in the analyses of macronutrient intakes because exclusion of presumed misreporters could bias the results as well ${ }^{(32)}$.

\section{Macronutrient intake deviates from recommendations and intake differs between age classes}

The reported percentage of EI from fat, SFA and carbohydrates deviates from the Belgian dietary reference intakes (total fat $<30 \mathrm{E} \%$, SFA $<10 \mathrm{E} \%$ and carbohydrates $>55$ $\mathrm{E} \%)^{(33)}$, especially for the oldest age group (40E \% total fat, $17 \mathrm{E} \% \mathrm{SFA}$ and $43 \mathrm{E} \%$ carbohydrates). The younger age categories had a lower fat and SFA intake and a higher carbohydrate intake than the older age categories. The higher carbohydrate intake of younger persons is mostly from mono- and disaccharides. The results for fat content and fatty acid composition of the age class 15-18 years are in line with the recent results of Belgian adolescents of $13-18$ years of age ${ }^{(34)}$.

Intake of total fat (46E \%) and SFA (19E \%) in Belgium in 1980-4 ${ }^{(1)}$ was even higher, and intake of carbohydrates was lower $(42 \mathrm{E} \%)$ than that in the oldest age class of the present study.

Comparisons with the BIRNH study and differences between age classes of the present study suggest that macronutrient composition indeed has been changing over the last 20 years towards a lower total and SFA intake and a higher sugar intake. The lowering of the SFA content of the diet is promising in the light of prevention of $\mathrm{CHD}^{(35)}$.

A lowering of total fatty acid intake was also observed in other food consumption surveys conducted in the Netherlands ${ }^{(36)}$ and Great Britain ${ }^{(37)}$. The British National Diet and Nutrition Survey ${ }^{(37)}$ also observed a lowering of the SFA content in the 2000 survey than in the 1986-7 survey. In contrast, in Germany, no decrease in total fatty acid intake was observed in the older population, but only in the younger age groups $^{(38,39)}$. Most important contributors of saturated fat intake differ between countries ${ }^{(40)}$. In Belgium, to reduce SFA intake, further efforts could be made to reduce SFA from butter, margarine, cheese and meat by reducing their intake or by choosing leaner variants.

Restriction of sugar intake is likely to contribute to reducing the risk of unhealthy weight gain ${ }^{(41)}$. The population intake goal for free sugars is below $10 \%$ of total energy ${ }^{(42)}$. Of the Belgian population, $96 \%$ exceed the upper level of sugar intake; current intake of mono- and disaccharides is twice this level. Especially, in the youngest age group, sugar intake is high $(24 \mathrm{E} \%)$, whereas in the oldest age group, the intake is the lowest (19 E \%). The British National Diet Nutrition Survey ${ }^{(37)}$ noted similar age differences in sugar intake. In the UK, the main source of mono- and disaccharides was soft drinks as in Belgium. Soft drinks contributed $33 \%$ to the mean intake of sugars in the youngest age groups in Belgium and $37 \%$ in the $\mathrm{UK}^{(25)}$. In Belgium, $59 \%$ respondents in the age category $15-18$ years consumed more than one can $(330 \mathrm{ml})$ of soft drink per day. Higher consumption of sugar-sweetened beverages is associated with a greater magnitude of weight gain and increased risk for the development of type 2 diabetes in women, possibly by providing excessive energies and large amounts of rapidly absorbable sugars $^{(43,44)}$, although no consensus has been reached $^{(45)}$.

\section{Comparison with dietary surveys}

As an overall trend, it can be noted that the reported EI is lower in the BNFCS than in the BIRNH study even when the underreporters are excluded from the dataset.

Total fat intake is 7.2 (for men) to 8.6 (for women) E\% lower in the BNFCS than in the BIRNH study. SFA intake is $3 \mathrm{E} \%$ lower than that in the BIRNH study. Carbohydrate intake is $3-4 \mathrm{E} \%$ higher than that in the BIRNH study ${ }^{(2)}$.

Time trends in energy and macronutrient intakes between 1994 and 2002 were investigated in Germany as well in an ageing population in Giessen (GISELA study, a longitudinal study on nutrition and health status). The dietary intake was assessed via a $3 \mathrm{~d}$ estimated dietary record. A total of 2135 records from 532 subjects, aged 60 years and over, were analysed. Energy and macronutrient intakes of the GISELA subjects stayed fairly stable over the study period ${ }^{(39)}$. The Dortmund Nutritional and Anthropometric Longitudinally Designed study evaluated 15-year time trends in long-term energy and macronutrient intake data on the basis of $3 \mathrm{~d}$ weighed dietary records of 795 infants, children and adolescents since 1985 in Germany. Also in these age groups, no significant changes in intakes of energy, protein, PUFA and added sugars were found. Fat intake decreased significantly in all age groups (between -0.20 and $-0.26 \mathrm{E} \% /$ year), as well as intake of SFA (between -0.11 and $-0.14 \mathrm{E} \%$ / year) ${ }^{(38)}$

In the Republic of Ireland and Northern Ireland, a food consumption survey collected food intake data using a $7 \mathrm{~d}$ food diary in the period 1997-9 (n 1379 adults aged 18-64 years). Mean daily EI in men were $11 \mathrm{MJ} / \mathrm{d}, 15 \cdot 5 \mathrm{E} \%$ was derived from protein, $34.8 \mathrm{E} \%$ from fat and $43.5 \mathrm{E} \%$ from carbohydrate. Corresponding figures for women were $7.6 \mathrm{MJ} / \mathrm{d}$, $15 \cdot 6,35 \cdot 6,45 \cdot 1$ and $3 \cdot 5 \mathrm{E} \%{ }^{(46)}$.

The surveys conducted in Estonia, Latvia and Lithuania in the summer of 1997 collected information using a $24 \mathrm{~h}$ recall of dietary intake. Representative national samples of adults were selected (Estonia, $n$ 2015; Latvia, $n$ 2300; Lithuania, $n$ 2094). The mean proportion of energy from fat was high in each country, but particularly in Lithuania $(44 \%)$ and Latvia $(42 \%)$ than in Estonia $(36 \%)^{(47)}$

In France between February 2006 and March 2007, a survey was done in 3115 subjects aged 18-74 years. Energy and macronutrient intakes were estimated using three randomly 
distributed $24 \mathrm{~h}$ recalls. When compared with the current recommendations, especially the intake of carbohydrates $(>50 \%$ EI) and the intake of SFA $(18.5 \%)$ were unsatisfactory ${ }^{(48)}$.

\section{Methodological aspects}

Although, undoubtedly, (un)willingness to participate leads to some selection bias, these data represent a more general population of Belgium who are at least 15 years old in comparison with other studies in Belgium, which are mostly restricted to local areas. Great efforts have been made to select a representative sample of the Belgian population for this survey.

The participation rate was, however, below $50 \%$. Nonresponders were replaced by beforehand selected reserve persons of the same sex and age and living in a household of the same size and in the same commune as the originally selected persons. In the phase of statistical analyses, in addition, the sample was weighed to the age and sex distribution of the Belgian population in 2004. In addition, emphasis was put on standardising methods of dietary assessment by using standardised software and training the dietitians.

For the comparison of the current data with the data of the BIRNH study, it is important to realise that the studies had different objectives, design, characteristics of the study population, dietary assessment and data analyses methodology. This limitation also applies to the comparisons made with results from dietary surveys conducted in other countries. The BIRNH study was designed as an ecological study to investigate about the regional patterns of food consumption. Diet was assessed by a $1 \mathrm{~d}$ food record in a random sample of 11000 inhabitants of Belgium. Furthermore, different versions of food composition tables were used to convert foods in nutrients, and the analyses were not weighed for the age and sex distribution of the Belgian population.

\section{Conclusion}

The dietary macronutrient intakes of the participants in the BNFCS deviate from the National Dietary Guidelines. Macronutrient intake differs between age classes with a lower intake of SFA and higher intake of sugars in the younger age classes than in the older age classes. Further efforts are necessary to improve the macronutrient composition of our diet, taking into account these differences. In addition, it will be important to monitor its changes regularly.

\section{Acknowledgements}

The authors acknowledge the work of Stephanie De Vriese and Michel Moreau during the design and field work of the study. Dietary support from Mia Bellemans, Mieke De Maeyer, Kadija El Moumni and Davy Van Steenkiste is highly appreciated. The authors specially thank the respondents and dietitians of the field work. This survey was funded by the Federal ministry of Health, Food Chain Safety and Environment. The authors declare that they have no conflict of interest.

\section{References}

1. BIRNH (1989) BIRNH - The Belgian Interuniversity Research on Nutrition and Health Study Group. Acta Cardiol 64, 89-194.

2. De Henauw $S$ \& De Backer G (1999) Nutrient and food intakes in selected subgroups of Belgian adults. Br J Nutr 81, Suppl. 2, S37-S42.

3. Belgische Hoge Gezondheidsraad (2003) Voedingsaanbevelingen voor België, herziene versie 2003 (Nutrition Recommendations for Belgium, Revised 2003). Brussels: Belgische Hoge Gezondheidsraad.

4. Brussaard JH, Lowik MR, Steingrimsdottir L, et al. (2002) A European food consumption survey method - conclusions and recommendations. Eur J Clin Nutr 56, Suppl. 2, S89-S94.

5. Brussaard JH, Johansson L \& Kearney J (2002) Rationale and methods of the EFCOSUM project. Eur J Clin Nutr 56, Suppl. 2, S4-S7.

6. De Henauw S, Brants HA, Becker W, et al. (2002) Operationalization of food consumption surveys in Europe: recommendations from the European food consumption survey methods (EFCOSUM) project. Eur J Clin Nutr 56, Suppl. 2, S75-S88.

7. De Vriese S, Debacker G, De Henauw S, et al. (2005) The Belgian food consumption survey: aims, design and methods. Arch Public Health 63, 1-16.

8. Slimani N \& Valsta L (2002) Perspectives of using the EPICSOFT programme in the context of pan-European nutritional monitoring surveys: methodological and practical implications. Eur J Clin Nutr 56, Suppl. 2, S63-S74.

9. NUBEL (2004) Belgian Food Composition Table, 4th ed. Brussels: Ministry of Public Health (in Dutch).

10. NEVO (2001) NEVO-Table, Dutch Food Composition Table 2001. Zeist: NEVO Foundation (in Dutch).

11. Insitut Paul Lambin (2004) Table de composition des aliments (Food Composition Table). Brussels: Institut Paul Lambin.

12. Food Standards Agency (2002) McCance and Widdowson's The Composition of Foods, 6th summary ed. Cambridge: Royal Society of Chemistry.

13. Schofield WN (1985) Predicting basal metabolic rate, new standards and review of previous work. Hum Nutr Clin Nutr 39, Suppl. 1, 5-41.

14. Goldberg GR, Black AE, Jebb SA, et al. (1991) Critical evaluation of energy intake data using fundamental principles of energy physiology: 1. Derivation of cut-off limits to identify under-recording. Eur J Clin Nutr 45, 569-581.

15. Palaniappan U, Cue RI, Payette H, et al. (2003) Implications of day-to-day variability on measurements of usual food and nutrient intakes. J Nutr 133, 232-235.

16. Beaton GH, Milner J, Corey P, et al. (1979) Sources of variance in 24-hour dietary recall data: implications for nutrition study design and interpretation. Am J Clin Nutr 32, 2546-2559.

17. Mennen LI, Bertrais S, Galan P, et al. (2002) The use of computerised $24 \mathrm{~h}$ dietary recalls in the French SU.VI.MAX Study: number of recalls required. Eur J Clin Nutr 56, 659-665.

18. Nelson M, Black AE, Morris JA, et al. (1989) Between- and within-subject variation in nutrient intake from infancy to old age: estimating the number of days required to rank dietary intakes with desired precision. Am J Clin Nutr 50, 155-167.

19. Neuhaus JM, Murphy SP \& Davis MA (1991) Age and sex differences in variation of nutrient intakes among U.S. adults. Epidemiology 2, 447-450.

20. Nusser SM, Carriquiry AL, Dodd KW, et al. (1996) A semiparametric transformation approach to estimating usual daily intake distributions. J Am Stat Assoc 91, 1440-1449.

21. Institute of Medicine (IOM) (2003) Dietary Reference Intakes: Applications in Dietary Assessment [Food and Nutrition Board, editor]. Washington, DC: National Academy Press. 
22. Guenther PM, Kott PS \& Carriquiry AL (1997) Development of an approach for estimating usual nutrient intake distributions at the population level. J Nutr 127, 1106-1112.

23. Iowa State University (1996) A User's guide to C-SIDE. Software for Intake Distribution Estimation. Technical Report 96-TR 31. Department of Statistics and Center for Agricultural and Rural Development, Iowa State University. Ames, IA.

24. Goldberg GR, Black AE, Jebb SA, et al. (1991) Critical evaluation of energy intake data using fundamental principles of energy physiology: 1 . Derivation of cut-off limits to identify under-recording. Eur J Clin Nutr 45, 569-581.

25. Singh R, Martin BR, Hickey Y, et al. (2009) Comparison of self-reported, measured, metabolizable energy intake with total energy expenditure in overweight teens. Am J Clin Nutr 89, $1744-1750$.

26. Abbot JM, Thomson CA, Ranger-Moore J, et al. (2008) Psychosocial and behavioral profile and predictors of self-reported energy underreporting in obese middle-aged women. $J \mathrm{Am}$ Diet Assoc 108, 114-119.

27. Mendez MA, Wynter S, Wilks R, et al. (2004) Under- and overreporting of energy is related to obesity, lifestyle factors and food group intakes in Jamaican adults. Public Health Nutr 7, 9-19.

28. Lissner L (2002) Measuring food intake in studies of obesity. Public Health Nutr 5, 889-892.

29. Ferrari P, Slimani N, Ciampi A, et al. (2002) Evaluation of under- and overreporting of energy intake in the 24-hour diet recalls in the European Prospective Investigation into Cancer and Nutrition (EPIC). Public Health Nutr 5, 1329-1345.

30. Zhang J, Temme EH \& Kesteloot H (1999) Sex ratio of total energy intake in adults: an analysis of dietary surveys. Eur $J$ Clin Nutr 53, 542-551.

31. Zhang J, Temme EH, Sasaki S, et al. (2000) Under- and overreporting of energy intake using urinary cations as biomarkers: relation to body mass index. Am J Epidemiol 152, 453-462.

32. Black AE, Goldberg GR, Jebb SA, et al. (1991) Critical evaluation of energy intake data using fundamental principles of energy physiology: 2. Evaluating the results of published surveys. Eur J Clin Nutr 45, 583-599.

33. Hoge Gezondheidsraad (2003) Voedingsaanbevelingen voor België - Herziene versie 2003 (Nutrition Recommendations for Belgium - Revised version 2003), no. 9076994-19-6. Brussels: Hoge Gezondheidsraad.

34. Matthys C, De Henauw S, Bellemans M, et al. (2006) Sources of saturated fatty acids in Belgian adolescents' diet: implications for the development of food-based dietary guidelines. Br J Nutr 95, 546-554.
35. Kromhout D, Menotti A, Kesteloot H, et al. (2002) Prevention of coronary heart disease by diet and lifestyle: evidence from prospective cross-cultural, cohort, and intervention studies. Circulation 19, 893-898.

36. Beheerscommissie Voedselconsumptiepeiling (1998) Zo eet Nederland resultaten van de voedselconsumptiepeiling 1998 (The Results of the Food Consumption Survey in The Netherlands 1998). 905177 0367. Den Haag: Voedingscentrum.

37. Swan G (2004) Findings from the latest National Diet and Nutrition Survey. Proc Nutr Soc 63, 505-512.

38. Alexy U, Sichert-Hellert W \& Kersting M (2002) Fifteen-year time trends in energy and macronutrient intake in German children and adolescents: results of the DONALD study. $\mathrm{Br} J$ Nutr 87, 595-604.

39. Jungjohann SM, Luhrmann PM, Bender R, et al. (2005) Eight-year trends in food, energy and macronutrient intake in a sample of elderly German subjects. Br J Nutr 93, 361-378.

40. Naska A, Fouskakis D, Oikonomou E, et al. (2006) Dietary patterns and their socio-demographic determinants in 10 European countries: data from the DAFNE databank. Eur $J$ Clin Nutr 60, 181-190.

41. WHO (1990) Diet, Nutrition, and the Prevention of Chronic Diseases: Report of a WHO Study Group 797. Geneva: WHO.

42. Hoge Gezondheidsraad (2003) Voedingsaanbevelingen voor België herziene versie 2203 (Nutrition Recommendations for Revised 2203). 7145/1. Brussels: FOD Volksgezondheid Leefmilieu en Veiligheid van de Voedselketen.

43. Malik VS, Schulze MB \& Hu FB (2006) Intake of sugarsweetened beverages and weight gain: a systematic review. Am J Clin Nutr 84, 274-288.

44. Schulze MB, Manson JE, Ludwig DS, et al. (2004) Sugarsweetened beverages, weight gain, and incidence of type 2 diabetes in young and middle-aged women. JAMA 292, 927-934.

45. Forshee RA, Anderson PA \& Storey ML (2008) Sugarsweetened beverages and body mass index in children and adolescents: a meta-analysis. Am J Clin Nutr 87, 1662-1671.

46. Harrington KE, McGowan MJ, Kiely M, et al. (2001) Macronutrient intakes and food sources in Irish adults: findings of the North/South Ireland Food Consumption Survey. Public Health Nutr 4, 1051-1060.

47. Pomerleau J, Mckee M, Robertson A, et al. (2001) Macronutrient and food intake in the Baltic republics. Eur J Clin Nutr 55, 200-207.

48. Castetbon K, Vernay M, Malon A, et al. (2009) Dietary intake, physical activity and nutritional status in adults: the French nutrition and health survey (ENNS, 2006-2007). Br J Nutr 102, 733-743. 